\title{
COMPETING HIERARCHIES: JAVANESE MERCHANTS AND THE PRIYAYI ELITE IN SOLO, CENTRAL JAVA
}

\author{
Suzanne A. Brenner
}

"Everyone wants to be priyayi. The ones who are already priyayi want to become even more priyayi. The rich ones want to be richer. The ones with rank want higher rank. All of them are priyayi. Rank, wealth, title, that's what being priyayi is about. Any one of those alone, that's priyayi. Not to mention all three of them at once. Prepare yourself, my daughter. The time has come."

-Arswendo Atmowiloto, Canting (1986)

The eighth month of the Islamic-Javanese lunar calendar is called Sadran, Sya'ban, or, more commonly, Ruwah. During this month, which directly precedes the Muslim fasting month (Ramadhan), Javanese villagers and city folk alike make individual and group visits to the grave sites of ancestors and other relatives, venerated Islamic teachers, mystics, legendary figures, the first settlers of their villages, and any others from whom they wish to request blessings (nyuwun pangèstu, nyuwun berkah), or for whose souls they wish to offer prayers. The ritual of visiting graves during this month is known as sadranan or ruwahan. Ruwah is the time when people return to their natal or ancestral villages to make offerings at the graves of their forebears, and make pilgrimages to grave sites too distant for a casual weekly visit on a Thursday night or Friday morning, the usual time to "send" (ngirim) flowers, prayers, and incense to the spirits of the dead.

It was toward the end of the month of Ruwah that I was invited to accompany several neighbors on a day-trip to Kotagede, in the Special Region of Yogyakarta. Early on a Monday morning five of us piled into a chauffeur-driven passenger van belonging to the

Research for this article was conducted as part of my dissertation research from 1986 to 1988 in Solo, Central Java, under the auspices of the Indonesian Institute of Sciences and the Center for Cultural Studies of Gadjah Mada University. Research and writing were funded by a Fulbright-Hays Dissertation Research Fellowship, a Social Science Research Council Dissertation Research Grant, and a Woodrow Wilson Research Grant in Women's Studies. I am grateful to James Siegel, Benedict Anderson, Nancy Florida, P. Steven Sangren, and Kathryn March for their comments on earlier drafts of this essay. 
wealthy merchant couple that had organized the trip, the Sapardis ${ }^{1}$, who were in their late sixties. About two hours later, we arrived at the royal cemetery of Kotagede, established in the late sixteenth century. This is the burial place of the founders of the kingdom of Mataram, ancestors to the present-day royal houses of Solo and Yogyakarta. ${ }^{2}$

Upon entering the high-walled complex, which had only a few other visitors, we removed our shoes as a sign of respect, and changed our clothes in a room designated for that purpose. The one man in our group, Pak Sapardi, changed his Western-style clothing for full formal Javanese attire, donning a high-collared white jacket, a Solonese batik sarong, and a blangkon, the stiff batik headdress worn by men. The women, who were already wearing batik sarongs, replaced their usual long-sleeved blouses (kebaya) with kemben, a simple breast cloth that leaves the shoulders bare, in the style worn at court by female servants and noblewomen of all but the highest ranks. Before entering the inner courtyard, a gatekeeper wearing the regalia of a court retainer ( $a b d i$ dalem) asked us politely to remove our jewelry and watches. The reason, I was told by a member of my party, was so that we would not appear to be "trying to put ourselves on the same level" with the royalty buried there: in the presence of royal graves one dressed the same way that one would dress for a formal audience if their inhabitants were still alive. So, barefoot and dressed in the unadorned style of courtiers, we proceeded to sowan - to pay a visit to someone of superior status-to the tombs of the royal persionages interred in the inner sanctum of the cemetery.

Walking past the more minor graves, which were outdoors, we stopped at the doorway of a large mausoleum. Each member of the party sat cross-legged outside the door for a few minutes, without speaking, once again in the respectful manner of a courtier. Before going inside, everyone performed a sembah, an obeisant gesture made by holding the hands before the face, palms pressed together and thumbs approaching the nose.

The inside of the mausoleum was dimly lit, illuminated only by occasional thin rays of sunlight that streamed through a few glass roof tiles and bevelled glass windows emblazoned with the insignia of Sunan Pakubuwana X of Solo (r. 1893-1939). The damp air was heavy with incense and the smell of fresh and decaying rose petals strewn liberally over all the tombstones. Members of the group greeted several male caretakers in formal Javanese clothing, who wore the yellow sash around their necks that indicated their status as abdi dalem. The Sapardis knew these men from their regular biannual visits to the cemetery during the months of Sura (Muharram, Arabic; the first month of the Islamic-Javanese year) and Ruwah.

\footnotetext{
1 The name Sapardi is a pseudonym.

2 Kotagede was established by Kyai Ageng Mataram, also known as Pamanahan (died 1575). The kingdom of Mataram was founded at Kotagede in 1587 by Panembahan Senapati Ingalaga, Kyai Ageng Mataram's son, after he destroyed the kingdom of Pajang. Senapati died in 1601 and was buried in the graveyard of the town mosque, next to the grave of his father. Other members of the royal family and high officials of the kingdom were buried there as well. This graveyard was subsequently made into a special compound and designated a royal cemetery. Even after the seat of Mataram was moved from Kotagede to Kerta by Sultan Agung, who built a new royal cemetery at Imogiri, the cemetery at Kotagede continued to be treated as a venerated site housing the graves of the ancestors of Later Mataram. Following the division of Later Mataram into the Sunanate of Surakarta (Solo) and the Sultanate of Yogyakarta in 1755, it was agreed that the royal cemeteries at Kotagede and Imogiri would be maintained jointly by the two courts as "ancestral lands" (tanah pusaka). For more on Kotagede and its royal cemetery, see H. J. van Mook, "Kuta Gede," in The Indonesian Town: Studies in Urban Sociology (The Hague and Bandung: van Hoeve, 1958) and Mitsuo Nakamura, The Crescent Arises over the Banyan Tree: $A$ Study of the Muhammadiyah Movement in a Central Javanese Town (Yogyakarta: Gadjah Mada University Press, 1983).
} 
As we approached the tombs of the most senior figures, which were on a dais raised above the level of the other graves, each person dropped to his or her knees and moved forward in a humble, half-crouching posture (laku dhodhok) used in the palaces for approaching someone of high rank. We sat cross-legged in front of the most important tombs. Two of the women burned incense in a small brazier and scattered flower petals over the tombstones. Pak Sapardi made a short introductory speech in very high Javanese, mentioning the names of the members of the party (excluding the anthropologist) who had come to pay respects to the dead buried there, and to pray that the souls of the deceased would be accepted by God and given a place in Heaven. He asked forgiveness from the spirits of the dead for any mistakes or offenses the members of the group might commit in their presence.

After he stopped speaking, the three abdi dalem whose services he had enlisted sat down before the tombs on the raised platform and chanted Arabic prayers for the souls of the dead. When these prayers were finished, Pak Sapardi, followed by the other members of the party in turn, inched forward in the same crouching walk until he was directly in front of one of the tombstones, uttered a prayer under his breath, then wiped his face afterwards with both hands in the gesture that follows an Islamic prayer. After this he moved even closer to the tombstone. With one hand touching the base of the tombstone, he knelt deeply in front of it, almost prostrate, his forehead and nose also touching the base. He moved his lips in a whisper for several minutes while remaining in that position. Upon completing this part of the ritual, he made a sembah before the tomb, then moved on to the next grave, where he repeated the whole routine. This went on at about ten tombs, which were arranged in tiers according to rank and seniority. The progression of the ritual was from the tombs of the most senior figures to those of lower rank.

Having gone around to each of the major tombs, the members of the group left the chamber, turned around, knelt, and performed a final sembah before departing the graveyard. After a brief chat with a few of the abdi dalem, a stroll around the rest of the grounds, and a picture-taking session just inside the main gates, we changed back into our street clothes and exited the complex. On the way out, Pak Sapardi distributed small coins from a plastic bag to women and children beggars who sat at the outer gates.

As we left the cemetery, I asked one of the women what she had whispered at each grave. The first part, she told me, was a prayer to God that the sins of the dead would be forgiven and their souls (arwah) accepted in Heaven; this was the Arabic prayer that ended in the face-wiping gesture. The second part, when she "kissed" the base of the tombstone, was a prayer offered up directly in high Javanese to the spirit of the person buried there, and consisted of requests for various blessings. The other members of the group had followed the same routine, it turned out. I asked her husband what favors he had requested from the spirits of the dead. "Health, lots of good fortune, and great profits," he answered without hesitation.

This was only one of many cemeteries that were visited by the Sapardis during the month of Ruwah; during that day alone we went to three other grave sites in the Kotagede area, and Bu Sapardi let me know that during a typical Ruwah she might visit well over fifty cemeteries. "It's better than just sitting around at home, isn't it?" she asked rhetorically. What was striking about this particular sadranan ritual at the Kotagede cemetery, however, was that it involved an open, completely unabashed display of obeisance and supplication to royalty - or at least, to the spirits of royalty-by people who on other occasions adamantly declared their absolute independence from, and disdain for, the hierarchies and values of the palaces. 
The Sapardis were the consummate representatives of the prosperous Javanese sudagar (merchant) couple: both had been born into well-established families that had enjoyed uninterrupted prestige in Solo's merchant community for several generations, not a small accomplishment considering the wild swings in fortune that many other merchants had experienced. ${ }^{3}$ The Sapardis' own textile business, founded in the 1930 s, had continued to thrive in the 1980s, a period when many similar businesses were foundering or had gone bankrupt. Their opulent home and gardens, situated behind a high wall crowned with barbed wire and impeccably maintained by a large house staff, were extraordinary by any standards. Their wealth, acumen in business, and family heritage gave them a degree of status in the Javanese merchant community that few others could match. Their female servants were expected to kneel while serving them and to avert their eyes submissively while speaking to them. Residents of Laweyan, a stronghold of ethnic Javanese merchants on the outskirts of the city who specialized in the manufacture and trade of batik cloth, the Sapardis had the self-assured air of people who had reached the pinnacle of success, at least by local standards. ${ }^{4}$ When they walked down the street, those of lesser status would move aside respectfully to let them pass.

Only a few days after arriving in Laweyan, a neighborhood that was known throughout Solo and beyond for its well-to-do, independent-minded Javanese sudagar families, I had been escorted to the Sapardis' home by a senior member of the household in which I was living. It soon became clear to me that this was a couple that commanded great respect, and not a little envy, serving as exemplars for the rest of the community. During the course of our conversation, Pak Sapardi stated proudly and in no uncertain terms, "The people of Laweyan have always had the spirit of entrepreneurs. Since the time of our ancestors, we haven't liked people telling us what to do. We don't like serving people. Our souls are the souls of entrepreneurs - we work for ourselves." He made no effort to hide his scorn for those whose livelihood depended upon catering to the will of others, especially those who served the palaces and the government bureaucracy. His wife indicated her full agreement, and I was to hear this sentiment expressed by many other residents of the neighborhood in the months to come.

Given their own almost "royal" stature in the Laweyan community, and their vehement declaration of independence from the true Solonese royalty and the values that they espoused, it was, then, most remarkable to see the Sapardis on their knees in Kotagede, nearly prostrate before the tombs of the ancestors of that same royalty. Their willingness to

\footnotetext{
3 The term sudagar (saudagar, Indonesian) means a medium- to large-scale merchant. It can refer to people who are involved in trade alone or in manufacturing as well as trade.

${ }^{4}$ Laweyan is one of a relatively small number of indigenous merchant enclaves found in Java. Other such communities include the devout Muslim community of West Kudus, long known for trade and for the manufacture of $k$ retek (clove cigarettes), and the merchant community of Kotagede, which included batik and silver manufacturers as well as pawnbrokers and diamond dealers. Although trade in Java tends to be associated with other ethnic groups, especially Chinese and Arab, each of these enclaves was famous for its successful Javanese entrepreneurs and merchants, particularly in the period from the mid- to late nineteenth century through the 1930s (and continuing into the 1960s, for instance, in the case of Laweyan). It is the indigenous merchant group on which I focus here. For a lengthier discussion of Laweyan, the batik industry, and the Solonese merchant community more generally, see Suzanne A. Brenner, "Domesticating the Market: History, Culture, and Economy in a Javanese Merchant Community" (PhD dissertation, Cornell University, 1991). On the entrepreneurs of Kudus, see Lance Castles, Religion, Politics, and Economic Behavior in Java: The Kudus Cigarette Industry (New Haven: Cultural Report Series no. 15, Southeast Asia Studies, Yale University, 1967) and Gretchen G. Weix, "Following the Family/Firm: Patronage and Piecework in a Kudus Cigarette Factory" (PhD dissertation, Cornell University, 1990). On Kotagede, see Nakamura, The Crescent Arises.
} 
humble themselves in this way was directly related, no doubt, to their expectation that they would receive the blessings of the dead in return. Implicitly, however, it was also an acknowledgment of their acceptance, if only partial, of the ideologies of the Javanese priyayi (aristocratic and bureaucratic) elite-the very ideologies that they claimed to disdain. Even when they made offerings at the graves of their own ancestors to ask for blessings of health and prosperity, they never performed the sembah, a sign of deference to those of high rank, since their forebears were, after all, only commoners.

Understanding the historical relationship between the Solonese priyayi and the sudagar class, two small but at one time very influential groups in the city, is important for what it reveals about the complexities of status and the cultural and ideological bases for the construction of hierarchy in Javanese society. Systemic conflicts between merchants and political elites are hardly unusual, especially in agrarian-based societies, where access to power and material wealth typically depends on control over land and labor rather than on control over commerce. In Java, where large-scale trade has been predominantly in the hands of people of foreign descent since the later seventeenth century-Dutchmen, Chinese, and Arabs, among others-one is not surprised to find the qualities generally linked with foreign trading minorities-avarice, a lack of social concern, a calculating rationalism and selfishness in place of a spirit of cooperation-attributed to the indigenous merchant class as well. During the colonial period, the indigenous merchants were unquestionably marginal to the mainstream of Javanese society, perhaps even more marginal than the nonindigenous merchants with whom they competed; for no clear niche was allotted to them in the colonial order, as was allotted, for example, to the ethnic Chinese, who had a well-defined position as middlemen. This marginality has continued into the postcolonial period, despite sporadic efforts of both the Old Order and New Order regimes to strengthen the position of indigenous entrepreneurs and merchants relative to nonindigenous groups.

The mistake of some scholars of Javanese society, however, has been to take this social marginalization as a sign of a basic difference in cultural outlook, a radical disjuncture between the values of the indigenous merchant class and those of the the wider population. In Peddlers and Princes, for instance, Clifford Geertz notes that "the pasar [marketplace] has tended to form a fairly self-contained cultural universe for its participants, while at the same time the status of the trader in the wider society has been ambiguous at best, pariah-like at worst." He writes in the same paragraph of the "historically persistent tension between the value system of the general society and that of the interstitial bazaar culture, and between peasant and gentleman on the one hand and trader on the other." 5 What I shall suggest in this essay is that the alleged cultural division between the Javanese merchant and "everyone else" is in important ways a fiction. In its internal social relations, linguistic formations, and cultural representations, the merchant community of Solo has recreated its own version of the hierarchies that underlie all other sectors of Central Javanese society. And hierarchy, as James Siegel has shown, is a fundamental value that permeates every sphere of Javanese society. ${ }^{6}$

But it is not quite accurate to assert that the values of the merchants are "the same" as those of other Javanese, for that, too, would be an oversimplification. Although the merchant community, like the peasantry or the aristocracy, has created its own patently

\footnotetext{
${ }^{5}$ Clifford Geertz, Peddlers and Princes: Social Development and Economic Change in Two Indonesian Towns (Chicago: University of Chicago Press, 1963), p. 44.

${ }^{6}$ James T. Siegel, Solo in the New Order: Language and Hierarchy in an Indonesian City (Princeton: Princeton University Press, 1986).
} 
Javanese hierarchies, it has done so primarily on the basis of something that is, from the perspective of priyayi ideology, outside the sphere of culture: money. Only among merchants, "the social representatives of unfettered equivalence," as Arjun Appadurai puts it, can one find a former household servant, who managed through luck and skill to build up a lucrative textile business, being treated as the social equal of the most established elites of the community. ${ }^{7}$ Yet the merchants of Laweyan, far from considering themselves to be "outside" Javanese culture, have done their utmost to uphold what they see as the most basic pillars of Javanese cultural life and tradition, particularly in their tireless attention to linguistic and behavioral etiquette and ritual detail-including some rituals that have been left behind by other sectors of the population.

The sudagar, then, have taken something that is, according to the dominant ideologies of the society, un-Javanese, and transformed it into something Javanese. This transvaluation of values $^{8}$ reproduces at a collective level a symbolic transformation that takes place daily at the level of the household: the conversion of money into a cultural object. ${ }^{9}$ Just as Javanese ideology tends to deny women, who are closely associated with money in the household as well as in trade, the status of fully enculturated beings, merchants as a class, male as well as female, are often considered to be less than fully Javanese. But from the viewpoint of the merchants themselves, as well as from the perspectives of women (the two categories overlap significantly, in fact, but for the time being I shall speak of them separately), transacting money does not preclude participating in the broader cultural order; on the contrary, it makes such participation possible. Money provides the means for the reproduction of the family and its social status. In the merchant community, money begets deference. The assimilation of money to hierarchy, in short, is what gives it its cultural value.

I shall return to this later. At this point, I tum again to the division between merchant and priyayi, in order to illuminate the tensions inherent in a social system in which there is a basic disjunction between political power, wealth, and status, at the same time that the dominant ideologies of that society insist on their unity. I focus here on the major royal house of Solo, the Kraton Solo (Solo Palace) or Kasunanan (Sunanate), and on the merchant community of Laweyan.

\section{A Legend of Defiance: Pakubuwana's Misadventures in Laweyan}

In the context of modern Indonesia under the New Order regime, both the Kraton and Laweyan stand as vestiges of a bygone era. Behind the imposing whitewashed walls surrounding the Kraton compound one expects to find the inherited riches of an almost 250year-old history. Instead, one finds timeworn buildings, sparsely furnished and inhabited, filled with little more than the lassitude of a dissolute and largely impoverished aristocracy. To speak of any real political power on the part of the Kraton would be absurd, since this descendant house of the once preeminent kingdom of Mataram had come completely under the control of the Dutch colonial regime by the end of the Diponegoro War (1825-1830). Moreover, the Sunanate of Solo, unlike the Sultanate of Yogyakarta, lost its claim to special political status after independence. While the Sultan of Yogyakarta and the Prince of the Pakualaman court (Yogyakarta's minor palace) maintained the right to participate in

\footnotetext{
7 Arjun Appadurai, "Introduction: Commodities and the Politics of Value," in The Social Life of Things: Commodities in Cultural Perspective, ed. Arjun Appadurai (Cambridge: Cambridge University Press, 1986), p. 33

8 I owe this phrase to James Siegel.

${ }^{9}$ Cf. Janet Carsten, "Cooking Money: Gender and the Symbolic Transformation of Means of Exchange in a Malay Fishing Community," in Money and the Morality of Exchange, ed. Jonathan Parry and Maurice Bloch (Cambridge: Cambridge University Press, 1989), pp. 117-42.
} 
governing what became known as the Special Region of Yogyakarta, Solo was deprived of "Special Region" status and neither the sunan nor the ruler of the Mangkunagaran house have had any official role in the republican government since that time. ${ }^{10}$

Although the Kraton had lost a great deal of its effective power, then, by the mid-nineteenth century, it nevertheless continued to envision itself-and was in turn envisioned by much of the population-as the pinnacle of the Solonese social and cultural hierarchy for the duration of the colonial period and beyond. The symbiotic relationship between Dutch overlord and local nobility that characterized colonial rule in Java enabled the Kraton (like the Sultanate of Yogyakarta and the two minor royal houses of the Vorstenlanden, or Principalities) to maintain considerable symbolic power in Javanese society while its actual power to govern the populace became increasingly limited. Even as the functionaries of an alien regime, the royalty continued to dominate Solo's social landscape. However, the lack of education, gradual impoverishment, and self-absorption of the royal family after independence, along with its failure to gain permanent political concessions from the government of the republic, led to a marked decline in the respect that the Kraton was able to command from the population. While it is still prestigious in Solonese society today to hold a title from the Kraton, an indication that the nobility continues to carry some symbolic weight, there is at the same time widespread cynicism toward the royalty, and a general belief in the community that a noble title can be purchased from the Kraton by anyone who has the money and inclination to do so.

The neighborhood of Laweyan, too, has an eerily anachronistic and debilitated air about it. Many of its batik workshops and immense homes are empty and decaying, their cracked and peeling walls, cobweb-covered dye vats, and broken stained-glass windows a reminder of an earlier, more prosperous time in the kampung's history, when the batik industry seemed an almost limitless source of wealth. There are exceptions to this general decline, such as the well-kept homes of the Sapardis and some of their neighbors, who continue to operate profitable businesses of one sort or another. But in Solo, the name Laweyan itself has become associated with a rapidly fading mercantile ethos and an old-fashioned way of life. In this latter sense as well it may be compared to the Kraton, which is seen as the symbolic center of Javanese tradition in Solo and throughout much of Java, but which is also considered to be largely irrelevant to the workings of the modern political, social, and economic order.

To speak of the relationship between Laweyan and the Kraton is to speak of the past, then, for although sentiments of mutual suspicion and resentment continue to be voiced on both sides late in the twentieth century, the sources of conflict between them date back to an earlier period. According to local legend, in fact, the strained relations between the merchants of Laweyan and the Javanese royalty originated just prior to the establishment of the Karaton Surakarta Hadiningrat (otherwise known as the Kraton Solo or Kasunanan) in 1746 by Sunan Pakubuwana II (r. 1726-1749), who was placed on the throne there by the expanding Dutch East India Company (VOC) in exchange for his cession to the Company of the portion of Java's north coast under his control.

Pakubuwana II had initially come to the throne in 1726 at the court of Kartasura, located about seven miles west of Solo, which was first established as a seat of power in 1680 . Following a lengthy period of political intrigue, power struggles, popular discontent, and ulti-

\footnotetext{
${ }^{10}$ For an analysis of the events that determined the political fates of the Solo and Yogyakarta royal houses after independence, See Benedict R. O'G. Anderson, Java in a Time of Revolution: Occupation and Resistance 1944-1946 (Ithaca: Cornell University Press, 1972), esp. pp. 350-69.
} 
mately, an armed rebellion that pitted local Javanese and Chinese against the allied forces of Pakubuwana II and the Dutch East India Company, rebel forces ravaged the palace at Kartasura, and Pakubuwana II fled eastward in June 1742. As M. C. Ricklefs puts it, Pakubuwana II "fled into the arms of the Company, who accepted this ... friendship on several conditions, most notably that the whole of the [north] coast would be placed under the Company's jurisdiction."11 The rebels were finally put down later that year by the troops of Prince Cakraningrat IV of Madura, who was an ally of the Company and the brother-inlaw of Pakubuwana II, and Pakubuwana was restored to the throne in 1743, his power, however, much diminished. Instead of attempting to rebuild the palace at Kartasura, which appeared to be an ill-fated site for the Kraton, he decided to move the entire court a few miles east to the village of Solo, near the banks of the Solo River (Bengawan Solo). The building of the new Kraton at its present site was completed in 1745, and Pakubuwana and his courtiers had taken up residence there by $1746 .^{12}$

A legend that is told today in Solo, most commonly in Kraton circles, dates the inception of the antagonism between Laweyan and the Kraton to the historical moment when Pakubuwana II was fleeing Kartasura, after his palace had been overtaken by the rebels. Although there are quite a few variations on the story, I offer here an abridged translation of one popular version, which was written down in modern Javanese by Samsudjin Probohardjono, a courtier of the Kraton, in 1981:

Three hundred years ago, the village of Laweyan was already famous as the home of wealthy merchants who dealt in thread (lawé), woven cloth, and batik. Their large walled houses loomed up everywhere. Their vast yards were surrounded by brick walls that were as thick and high and strong as the walls of the palace.

There are some who hold the opinion that the people of Laweyan were by nature strongly inclined toward trade, working only for themselves, and being entrepreneurs. This was a far cry from the honor and prestige of serving the King or the State. The greatness of their rank, the loftiness of their status, what was good and bad, were all determined by wealth and worldly riches.

The story is told that on June 30,1742 A. D., the Palace at Kartasura was ravaged by Chinese soldiers. His Royal Highness Pakubuwana the Second, together with his son the Crown Prince and his entourage, all of whom had just fled from the palace, were traveling east on horseback. Passing Pajang, they reached the eastern side of the Premulung River, where they rested for a spell to put all their things in order, as well as to rest their tired horses, which had not been tended to for several days due to the battle that raged, and because the Chinese soldiers were hot in pursuit.

While they rested there, His Highness sent a retainer to the village of Laweyan to borrow fresh horses that could be used to ride and to carry their supplies for the remainder of the journey. But none of the people of Laweyan were willing to offer their horses, since all were being used to transport their wares, trade being very brisk at the time.

\footnotetext{
11 M.C. Ricklefs, Modern Javanese Historical Tradition: A Study of an Original Kartasura Chronicle and Related Materials (London: School of Oriental and African Studies, University of London, 1978), p. 11.

12 For a straightforward account of the events leading up to and following the move of the Kraton from Kartasura to Solo, see M. C. Ricklefs, A History of Modern Indonesia c. 1300 to the Present (London: Macmillan, 1981), chapters 8 and 9; see also Ricklefs, Modern Javanese Historical Tradition, esp. pp. 10-11. A more interpretive and thoroughly enlightening account of the "royal progress" from Kartasura to Solo is found in John Pemberton, "The Appearance of Order: A Politics of Culture in Colonial and Postcolonial Java" (PhD dissertation, Cornell University, 1989), chapter 2.
} 
His Highness Pakubuwana the Second received this report with a heavy heart, thinking of how bad his luck was, facing the trials that the Almighty God was setting him. But then, calming himself, he said to himself clearly and firmly: "The people of Laweyan are not of the stature of priyayi, but are by nature traders who calculate profits and losses, who strive for wealth and treasures. May God the Almighty grant them these things."

The words of his Royal Highness Pakubuwana the Second, otherwise known as the Floating Sunan, have been true to this day. Many of the people of Laweyan have been successful in trade and in their firms. Many have become large-scale traders and entrepreneurs, very wealthy, their property and riches overflowing. But few have become priyayi or servants of Court and State with distinguished rank. ${ }^{13}$

This version of the story places the uppity people of Laweyan within the symbolic sphere of Kraton control by attributing their long-lasting success as merchants to the charity of Pakubuwana II and to the power and efficacy of his Word (sabda). In spite of their refusal to serve the sunan, he proves his own superiority and the superiority of the priyayi ethos by blessing them instead of cursing them.

In other versions of the story, though, Pakubuwana II is not quite so generous. Several people told me that when His Highness's request to borrow horses was turned down, he cursed the people of Laweyan, swearing that none of their descendants would ever be permitted to marry his descendants, and that henceforth, the people of Laweyan would be barred from attaining high rank in the Kraton, doomed forever to be low-status traders instead of honored priyayi. ${ }^{14}$ In fact, there does seem to be an informal rule in the Kraton, still in effect today, which enjoins high-ranking members of the royalty from marrying residents of Laweyan. Those who told me of this prohibition invariably cited the unfortunate experiences of Pakubuwana II in Laweyan as the reason for the prohibition. ${ }^{15}$

This legend was understandably more popular in Kraton circles than in Laweyan; many people in Laweyan seemed not to know the story or, if they had heard it, gave it little credence. However, an older Laweyan woman and her daughter related a version of the story that was generally similar to others but differed in one significant respect. I had asked the woman whether any member of the royalty had ever married into a Laweyan family, to her knowledge. "No," she answered simply, "That wasn't allowed by the Kraton. It was the word (sabda) of the sinuhun [sunan]." Her daughter, who was in her fifties, explained further. "People say that a woman from Laweyan was going to be made a concubine of the sinuhun, but she refused. The sinuhun was mad, and swore (nyebda, from sabda) that from that time on, from generation to generation, the people of Laweyan would never be close to the king, but they would be blessed with abundance" (Sa'turun-turuné wong Laweyan bakal adoh karo raja, nanging diparingi keluwihan). The older woman added that the name "Laweyan" came from luwih sembarang, meaning "more of everything." "More riches (luwih bandha-bandha), for instance," she explained.

${ }^{13}$ Samsudjin Probohardjono, "Sejarah Laweyan" (unpublished ms.), pp. 5-7. The translation is my own.

${ }^{14}$ According to one man, also a Kraton retainer of high rank, the sunan said to the people of Laweyan, "In the future, you will never become one with me" (sésuk, kowé ora isa manunggal karo aku).

${ }^{15} \mathrm{~A}$ few people suggested that the sunan, wishing to travel by water instead of by land, asked to borrow a ship, not a horse. Since the word kapal can mean either "ship" or "horse" in Javanese, the source of the ambiguity is understandable. This is not an implausible twist on the legend, since Laweyan is said to have bordered on a sizable tributary of the Solo River at that time. I might also mention that according to a resident of the Kraton, it was not Pakubuwana's request for transportation that was turned down, but his request for opium. That is not implausible, either, as local tradition has it that opium was one of the commodities traded widely in the area. 
This version of the story is especially telling, since it points to the unwillingness of the independent-minded women of Laweyan-for women clearly dominated trade in the neighborhood, as was typically true among Javanese merchants in the Solo-Yogyakarta region-to be placed under the control of aristocratic men. While many Javanese would have considered it an honor and a privilege to be made the wife or concubine of the sunan, Laweyan women were in general agreement that it was preferable to be a common but autonomous trader than to be kept as a royal consort, pampered but confined like a bird in a gilded cage, and forced to compete with other wives and mistresses for the attentions and favors of the men of the court. They found the idea of being dependent on men for everything (their stereotyped image of what it meant to be a woman of the nobility) to be especially unappealing, because most were accustomed to earning and saving their own money, with the freedom that provided. On several occasions people in Laweyan remarked disapprovingly that the ladies of the palace were little more than "vessels" (si wadhah) for bearing aristocratic children. ${ }^{16}$ They also took a dim view of the fact that Kraton consorts of common origin were expected to address their own royal children in the deferential language of high Javanese, while their children spoke ordinary low Javanese to them in return-a linguistic configuration that would be unthinkable in Laweyan or elsewhere outside of aristocratic circles.

Underlying the last version of the legend is a central but often overlooked point of distinction between the nobility and the merchant class in Solo. I shall argue presently that the different positions of women-or at least, the imagined differences-and their relations with men in these two groups accentuated, and in critical ways even defined, the social and symbolic gaps between them. For now, however, I merely wish to observe that, while this variant of the story highlights an important factor in the rift between aristocrat and merchant which hinges on the contrasting symbolic, social, and economic roles of women in the two communities (with the contrasts sometimes exaggerated, as will become clear), it does not stray from the basic theme that runs through all of the other versions. Like the others, it points to the averseness of the merchants of Laweyan to acknowledge Kraton hegemony, as indicated by their refusal to acquiesce to the sunan's wishes. It should be noted, however, that even in the rendering of the story by two Laweyan merchants, it is ultimately the sunan who decides the fate of Laweyan. He forbids its residents to attempt any rapprochement with the Kraton through marriage alliances or through direct service to the Sunanate, yet provides them with perpetual abundance by means of the magical potency of his word.

This legend expresses a palpable rift between the Javanese merchant class and the priyayi in Solo. It is difficult to pinpoint the origins of this fissure. Clearly one cannot make generalizations in this regard for the whole of Java, for the situation in the agrarian interior of the island, where Solo is situated, differed significantly from that of the commercially oriented north coast. In the thriving trading ports of Java's north coast in the centuries prior to colonization, political power and access to revenue among the nobility depended upon their ability to control commerce. ${ }^{17}$ While there may have been competition between aristocrats and merchants, there was little basis for a deep ideological conflict between them, because both depended in one way or another on trade for their livelihood and social status. Only when colonization permanently altered the face of socioeconomic relations in the region by

\footnotetext{
${ }^{16}$ Cf. Peter Carey and Vincent Houben, "Spirited Srikandhis and Sly Sumbadras: The Social, Political, and Economic Role of Women at the Central Javanese Courts in the 18th and Early 19th Centuries," in Indonesian Women in Focus: Past and Present Notions (Dordrecht: Foris Publications, 1987), p. 15, n. 5.

${ }^{17}$ See Pierre-Yves Manguin, "The Merchant and the King," above pp. 41-54, esp. pp. 47-48.
} 
shifting trade into the hands of Europeans, Chinese, and other foreigners did commerce cease to be a major source of political and economic strength for local elites.

In the fertile inland of Java, on the other hand, where economic and political power were based to a greater extent on control over land and the labor with which to work it, it is possible that trade was seen as a subordinate occupation that was ill suited to men (though perhaps not women-I shall come back to this point later) of rank. But there is little evidence from the precolonial period to sustain or disprove this speculation, and it is equally possible that the marginalization of the Javanese merchant in the interior was entirely a colonial development. Without question, this process of marginalization was carried to an extreme during the colonial period. From the very start of colonial intervention in the Indies, the Dutch East India Company had determined that it was safest and most efficient to put economic power into the hands of those who (besides themselves) had no political powermost notably, Chinese and other trading minorities, whom they could manipulate to their own advantage. In addition, the Company, and the government of the Netherlands East Indies that followed on its heels, made sure that indigenous rulers had limited access to wealth save through their ever-growing dependence on the colonial regime.

The divide-and-rule policy of the regime, then, extended to the economic as well as the political sphere. The formula was simple and quite effective: to keep independent access to wealth out of the hands of those with power, and power out of the hands of those with independent access to wealth. While Solo's palaces commanded substantial economic resources, including control over extensive agricultural lands and eventually over profitable sugar factories, their gradual erosion of power during the nineteenth and twentieth centuries made it evident to just what extent they relied on the Dutch for their well-being. Beginning in the early to mid-eighteenth century, Dutch subsidies were what really sustained the courts of Central Java. ${ }^{18}$ This was all the more apparent after the Indies government instituted the agrarian reorganization of the Vorstenlanden in the 1910s and 1920s, including the abolition of the long-standing appanage system, through which court functionaries had been assigned rights over fixed percentages of the produce of particular lands, as well as rights to a certain amount of corvée labor from the peasants. The abolition of this system, in conjunction with the spread of large European plantations, which cultivated crops like sugar, tobacco, and coffee for the international market, led to a serious reduction of power, prestige, and wealth on the part of the sunan and the Solonese priyayi as a whole. ${ }^{19}$

Whether or not the division between priyayi and sudagar actually originated with Dutch rule, the nature of colonial policy clearly served to exaggerate and rigidify that division. While supporting - and creating - priyayi ideologies that stressed service and self-sacrifice on behalf of the state as the noblest profession for a Javanese, ${ }^{20}$ and identifying the priyayi,

\footnotetext{
${ }^{18}$ M. C. Ricklefs, Jogjakarta under Sultan Mangkubumi 1749-1792: A History of the Division of Java (London: Oxford University Press, 1974); Ann Kumar, "Javanese Court Society and Politics in the Late Eighteenth Century: The Record of a Lady Soldier," Part I: "The Religious, Social, and Economic Life of the Court," Indonesia 29:1-46 (April 1980).

${ }^{19}$ For more on the effects of the agrarian reorganization in the Vorstenlanden, see Anderson, Java in a Time of Revolution, pp. 348-351; Takashi Shiraishi, An Age in Motion: Popular Radicalism in Java, 1912-1926 (Ithaca: Cornell University Press, 1990), chapter 1; George D. Larson, Prelude to Revolution: Palaces and Politics in Surakarta, 19121942 (Dordrecht: Foris Publications, 1987), pp. 20-22; Nakamura, The Crescent Arises, pp. 40-44; and Van Mook, "Kuta Gede," pp. 320-31.

${ }^{20}$ Both Heather Sutherland and Ann Kumar point out that over the course of the nineteenth century, the period during which the Dutch consolidated their control over the whole of Java and over the Javanese ruling class, the ideal of being a warrior (satria) in service to a powerful Javanese ruler gave way to an ideal of being an aristocratcum-bureaucrat (priyayi) in service to the colonial state (through the courts). See Heather Sutherland, The Making
} 
particularly those of the palaces of Central Java, as the standard-bearers of "high" Javanese culture, ${ }^{21}$ the European colonizers also declared emphatically that the Javanese people were by their very nature unfit as traders. The colonial bureaucrat Van Deventer, for instance, commented in 1904 that

Real thrift is foreign to the modern-day Javanese; money rolls through their fingers, or burns in their hands; the Chinese is thrifty, frugal, cautious at the same time. In the matter of free will, of the spirit of enterprise, the Native [Inlander] of Java has not come far either; his nature is rather docile.... Carefree also is the nature of the ordinary Javanese; they live from hand to mouth, and would rather think as little as possible about tomorrow; this source of a cheerful outlook on life, however, stands in sharp contrast with the inborn notion of the Chinese that people, as much as possible through material appearances, must uphold the sacred honor of their ancestors. Already in this one cardinal notion the Chinese possesses a mighty incentive to drive him to work, while the spirit of the Javanese knows nothing of this sort. ${ }^{22}$

Such assessments of "the Javanese character" appeared to justify the privileged position of nonindigenous sectors of the population with regard to trade, and the relegation of the Javanese themselves to the roles of happy peasant, carefree laborer, or docile government functionary. Although.much small-scale trade remained in the hands of Javanese-mostly Javanese women ${ }^{23}$-intermediate trade was controlled largely by ethnic Chinese, who did not have access to the prestige of colonial service, and who were afforded important business privileges by the colonial regime. ${ }^{24}$ The Dutch kept the very lucrative large-scale import-export trade for themselves. However, the increasing penetration of capital into the Vorstenlanden in the mid- to late nineteenth century was accompanied by the emergence of a small indigenous bourgeoisie, precisely at the time when the economic power and social prestige of the priyayi were waning as a result of colonial policies limiting their rights over land and the labor with which to work it. ${ }^{25}$ This class of indigenous merchants remained marginal to the mainstream of Javanese society, however, never becoming large enough or influential enough to alter the basic shape of colonial society.

The effective marginalization of the Javanese merchant class guaranteed that it could not create a serious challenge to the colonial state. As long as the priyayi, thoroughly coopted by the colonial regime, maintained their place at the apex of Javanese society and continued to look down upon the activities of the merchant, the wealth held by members of the numerically insignificant sudagar class was certain to remain quite harmless.

of a Bureaucratic Elite: The Colonial Transformation of the Javanese Priyayi (Singapore, Heinemann, 1979) and Kumar, "Javanese Court Society and Politics," Part II: "Political Developments: The Courts and the Company 1784-1791," Indonesia 30: 67-112.

${ }^{21}$ Nancy K. Florida, "Writing the Past, Inscribing the Future: Exile and Prophecy in an Historical Text of Nineteenth-Century Java" (PhD dissertation, Cornell University, 1990); Shiraishi, An Age in Motion.

${ }^{22} \mathrm{C}$. Th. van Deventer, Overzicht van den Economischen toestand der Inlandsche Bevolking van Java en Madoera (The Hague: Nijhoff, 1904), pp. 100-101.

${ }^{23}$ See Thomas Stamford Raffles, The History of Java, Vol. I (Kuala Lumpur: Oxford University Press, 1965), p. 353, on the dominance of women in the marketplace in the early nineteenth century.

24 On the collaboration of Chinese businessmen with the colonial regime, especially with regard to the opium revenue farms and the vast business networks that extended out from them, see James Rush, Opium to Java: Revenue Farming and Chinese Enterprise in Colonial Indonesia, 1860-1910 (Ithaca: Cornell University Press, 1990).

${ }^{25}$ Shiraishi, An Age in Motion, chapter 1. 
Benedict Anderson observes that the priyayi set themselves off from the rest of the Javanese population not only by rank and occupation, but also by lifestyle and the self-conscious adoption of a distinctive and highly elaborated system of ethical values. Within the priyayi ideology of spiritual potency, or Power, in Anderson's terminology, the active pursuit of material gain is seen as a sign of lack of refinement, which in turn indicates lack of status. As he writes:

Personal acquisitiveness, like sexual indulgence and political ambition, is one of the most obvious types of personal indulgence or pamrih. Accordingly, the overt pursuit of wealth that is characteristic of the merchant or businessman shows a lack of Power and therefore lack of status. This judgment should not be taken to suggest that the typical high-status Javanese is not a man of wealth or that the Javanese tradition does not conceive of riches as an important attribute of the ruler and his closest associates. But money in itself should never be the object of active pursuit. Wealth should flow to the holder of Power, as a consequence of that Power, in the same way that pusaka [sacred objects or heirlooms], large populations, wives, neighboring kingdoms or states flow toward the ruler, as it were, magnetically attracted to the center. The vast wealth that the great rulers of the Javanese past are described as possessing is always an attribute of Power, not the means for acquiring it. Thus in the Javanese political tradition wealth necessarily follows Power, not Power wealth. ${ }^{26}$

Moreover, wealth should not only flow to the holder of Power, it should also flow from him, as the result of his beneficence: "[W]ealth (or property) is an attribute of power, not its provenance; and socioeconomic status is a quality which derives from the center and has no meaning except in relation to that center." 27 The legend of Pakubuwana II's encounter with the merchants of Laweyan affirms the ideology that wealth should emanate from the center of power. By attributing Laweyan's riches to the all-powerful word of the sunan, the story suggests that even these intractable merchants, who refused the great honor of serving the king because they were more concerned with making money, ultimately owed their wealth to the sunan's formidable concentration of power and his beneficent nature. In reality, the Javanese merchant owed little or nothing of his or her wealth to the "powerful center," whether that center be identified with the palaces or with the colonial state (the distinction is ultimately an artificial one, of course). The merchant's accumulation of wealth therefore challenged the notion that wealth should either flow to, or be bestowed by, persons of high status.

\section{The "Suluk Mas Ngantèn": Rectifying Etiquette}

Even if we cannot establish with any certainty that the schism between merchant and priyayi in Solo dates back to the establishment of the Kraton there in the mid-eighteenth century, as the legend of Pakubuwana II and his horses would have us believe, an extraordinary Javanese poem from early nineteenth-century Solo gives undeniable evidence that the social categories of priyayi and sudagar were already considered to be distinct, essentially immutable, and fundamentally at odds with each other by that time. Composed in 1818 by Radèn Mas Riya Jayadiningrat I, a wayah dalem (grandson of the sunan), the "Suluk Mas Ngantèn" (roughly, "The Song of Mas Ngantèn") has a didactic yet humorous, even farcical

\footnotetext{
${ }^{26}$ Benedict R. O'G. Anderson, "The Idea of Power in Javanese Culture," in Culture and Politics in Indonesia, ed. Claire Holt, Benedict R. O'G. Anderson, and James Siegel (Ithaca: Cornell University Press, 1972), p. 41.

27 Ibid., p. 48.
} 
tone. ${ }^{28}$ The author states at the outset that his purpose in writing the poem is to advise young people never to fall short in following proper etiquette (aywa kurang ing tatakrami), so that they do not disgrace themselves. He then launches into a lengthy and very detailed description of some of the shameful shortcomings of people who aspire to be priyayi, but who do not know the tatakrama, etiquette or proper social conduct, of being priyayi (Ana cacad ageng nistha malih/wong nora wruh tatrap tatakrama/pratingkahing kapriyayèn).

The poem is divided into five sections, each describing a different scenario in which the failure to observe the etiquette proper to one's station in life leads to disastrous-and extremely comical-results. ${ }^{29}$ The fourth section, which is most relevant to the present study, concerns a petty merchant of Butuh (a village located on the Solo River) who, despite his distinctly non-priyayi status, wants to marry his child off in a priyayi-style wedding (kepengin cara priyayi) ${ }^{30}$ When the merchant, called simply "Mr. Merchant" (Ki Sudagar, Ki Juragan) confides his wish to "Mr. Adjutant" (Jajar Wajidan, Mas Wajidan ${ }^{31}$ ), a priyayi friend of his, Mr. Adjutant advises him that he would be better off not trying to imitate the priyayi. Mr. Merchant is determined, however, and Mr. Adjutant suggests that if Mr. Merchant is willing to entrust everything into his hands, he personally will see to all the preparations.

Ana maneh nisthane wong amemantu ana ta sudagar cilik sawatara sugihipun kepengin cara priyayi ana mitrane winanoh.

Kabeneran Jajar Wajidan ing ngayun asugih mitra priyayi rowang rembugan mantu alah adhi kadipundi gon kula arsa memanton.

Inggih kakang yen andhahar kula matur tan kadi tata priyayi kang raka alon amuwus dereng dhenger kula adhi tata pyayi kang sayektos.

Uwitipun kepengin celak priyantun mas Wajidan anyaguhi kakang sampun tumut-tumut

28 Radèn Mas Riya Jayadiningrat I, "Suluk Mas Ngantèn" (orig. composed Surakarta, 1818) in Serat Wulang (Jakarta: Departemen Pendidikan dan Kebudayaan, 1981), pp. 131-201. This poem is composed in a Javanese verse form that was meant to be sung to prescribed melodies. I am grateful to Nancy Florida for information about the original date of this text and the identity of the author, as well as for her very helpful suggestions and important corrections on my translation. I am also thankful to John Pemberton for encouraging me to look at the poem and for making a copy of the text available to me.

29 Each of the sections (pupuh) is written in a different meter with its standard corresponding melody and mood: Dhandhanggula, Sinom, Mijil, Megatruh, and Pucung.

${ }^{30}$ This fourth section is in the meter Megatruh, which Nancy Florida describes as a "melancholy metre." Florida, "Writing the Past," Vol. II, p. 668. Given the humorous nature of the scenes described here, the use of a melancholy sounding meter can only have added to the sharp satirical tone intended by the author.

31 Jajar is the lowest rank of Kraton official. Wajidan is the same as ajidan or ajudan, meaning, not surprisingly, "adjutant" (in service to the palace). Mas, which is sometimes used in the text in place of the official title Jajar, means "older brother," but it is also a general term of address for a man. It can also indicate low noble status. 
yen kakang sampun ngrojongi

sabarang dipun pitados.

Kang ngladosi miwah dandosan kang nyambut ngamungna kula pribadi

ki sudagar teka nurut mas Wajidan nuli pamit wus mubeng dennya wewartos.

Ngajak-ajak pawong-mitra dennya nyambut den ebang alungguh kursi

ana den ebang anayub

mitrane teka dalidir

wus pepak barang pirantos. 32

Again there is the shame of one who held a wedding

There was a petty merchant

Middling was his wealth

He yearned to follow the style of the priyayi

He had a friend

A jajar, as it happened, an adjutant at court

Had a wealth of priyayi friends

$\mathrm{He}$ joined in the discussion of the wedding

"Alas, adhi, ${ }^{33}$ how will it come to be

My desire to hold a wedding?"

'Well, kakang, if I may suggest to you

Don't try to do it priyayi style"

The elder one softly broke in

"I do not yet know, adhi

The true style of the priyayi

That is why I wish to be close to the priyayi"

Mr. Adjutant gave his promise

"Kakang, don't bother yourself

Kakang, if you agree

Just leave it all to me

For those who will serve, and the accessories, the procurer

Will be none but myself"

Mr. Merchant gave his assent

32 Jayadiningrat I, "Suluk Mas Ngantèn," Pupuh Megatruh, verses 1-6, pp. 182-83. In keeping with the transliterated version from which I have taken the Javanese text, all diacritics are omitted. It should be noted that I have translated only selected passages from the text, and that some of the translations offered here are admittedly tentative.

33 Adhi literally means "younger brother." Here, Mr. Merchant is addressing Mr. Adjutant, who is obviously younger than he is, in a friendly fashion. In return, Mr. Adjutant calls Mr. Merchant kakang, which literally means "older brother." Despite Mr. Adjutant's priyayi status, he speaks to Mr. Merchant in a somewhat higher level of Javanese (i.e., more respectfully) than Mr. Merchant speaks to him, although both speak to each other politely. For instance, Mr. Adjutant says that he wishes to matur (to speak to someone of higher status) to Mr. Merchant. The differences in language levels used by the two men fit with the junior and senior statuses indicated by their respective use of the terms of address "adhi" and "kakang." However, the language styles also show that Mr. Adjutant's priyayi status did not put him at a higher social level than Mr. Merchant. My thanks to Nancy Florida for pointing out the hierarchical nuances of the two men's speech styles. 
Mr. Adjutant then took his leave

Going around to spread the news

He invited his close friends, and borrowed from them

Promising that they could sit in chairs

Some were offered the prospect of a tayuban ${ }^{34}$

His friends came in great number

The equipment was complete

Although the wedding is still twelve days off, Mr. Adjutant and a number of his companions arrive unannounced at the home of Mr. Merchant, bearing a complete set of gamelan instruments and more equipment than the house will hold. When Mr. Merchant worries about who will guard the gamelan for twelve nights, Mr. Adjutant informs him that he has already invited a few more of his friends to help out, and suggests that Mr. Merchant's wife should prepare some simple food, "nothing fancy" (boten kedah opak-apik), and a little liquor, to keep them from getting sleepy. Mr. Merchant readily agrees to this. However, much to his dismay, that evening a great many priyayi guests show up, expecting to be lavishly provided with food, liquor, and entertainment:

Lagi wayah mahrib dhayoh wus barubul

akathah tur pyayi-pyayi

ki Wisma susah arikuh

mas Wajidan ngacarani

lah suwawi sami lungguh. ${ }^{35}$

At sunset the guests poured in

Many were they, and all priyayi

The host was ill at ease

Mr. Adjutant welcomed the guests

"Please, have a seat."

As the nervous host to such a distinguished group of guests, Mr. Merchant follows whatever Mr. Adjutant tells him to do, acceding to an increasingly expensive list of demands. The Chinese liquor (ciu) and Dutch gin (janéwer) flow liberally, the card games begin - with gambling money supplied to the guests by Mr. Merchant-and professional female dancers and gamelan musicians are called in, the latter given opium at Mr. Adjutant's urging. Throughout all this, Mr. Merchant pointedly ignores his wife's repeated protests:

Nyai Wisma malengos asalang gumun

kapriye padone iki

durung jagongan wus nayub

\footnotetext{
34 To be given a chair was a sign of honored status; people of lesser status would have sat on mats on the floor. Tayuban is a type of dance often performed in conjunction with weddings, annual village rites propitiating local tutelary spirits, and other ritual occasions. Male guests take turns dancing with one or two professional female dancers, known as tledhek or tandhak, who signal that it is a man's turn by extending him a long scarf. On tayuban, see Robert F. Hefner, "The Politics of Popular Art: Tayuban Dance and Culture Change in East Java," Indonesia 43 (1987): 75-94; see also Claire Holt, Art in Indonesia: Continuities and Change (Ithaca: Cornell University Press, 1967), pp. 111-13 and John Pemberton, "Musical Politics in Central Java (or How Not to Listen to a Javanese Gamelan)" Indonesia 44 (1987): 17-30. In the latter article, Pemberton also discusses the ceremonial role of chairs and Kraton restrictions on their use dating from the eighteenth century.

35 Jayadiningrat I, "Suluk Mas Ngantèn," Pupuh Megatruh, verse 17, p. 185.
} 
ki Sudagar manthelengi

wruha heh sira wong wadon ${ }^{36}$

The lady of the house turned her head in astonishment

"What's going on here

The wedding celebration hasn't started yet but you're already putting on a tayuban"

Mr. Merchant glared at her [saying]

"What do you know, you're just a woman!"

Mr. Merchant, who after a few drinks has overcome his anxiety and is feeling quite pleased with himself, becomes happily drunk, as do his guests, and everyone dances the night away at the tayuban.

On the morning of the actual wedding ceremony, however, none of the priyayi appear to accompany the groom to the place across the Solo River where the ceremony will be held. Besides the inebriated Mr. Adjutant, only the sudagar guests come to serve as escort. Although the merchants are dressed in fine clothes and jewelry, the procession is nonetheless sloppy and disorderly:

$\cdots$

duk panganten arsa kawin

pra priyayi tana rawuh

kapiran kang ngiring aring

kang saguh kabeh gedobrol.

Pra sudagar semune kemeren mutung

temah mangkat ting karenthil

mas Wajidan pijer wuru

sawiyah tungganganeki

wus mangkat nging reyah-reyoh.

- .

Watak-wantu yen sudagaran memantu sarwa emas sarwa keling wus mangkat pangarakipun

sarwa mubyar busana sri

pangantene nunggang belo.

Meh kapiran turangga tan ana ngingu punika napas barindhil rada rengkik dhasar kuru brang-wetan anambutneki kyai Kapedhak ing Beton. ${ }^{37}$

When the wedding was nigh

None of the priyayi came

In disarray the escort

All of their promises had been empty

36 Ibid., verse 39, p. 188.

37 Ibid., verses 51-56, p. 190. 
The merchants were all jealous and broken And so their departure was not in unison Mr. Adjutant was constantly drunk

Each of the vehicles

Had set off but was on the verge of collapse

Typical of a merchant wedding

All gold and silks

The procession was on its way

All shining in garments resplendent

The groom rode a young horse

Almost neglected was the horse, having received little care

It was a bald roan horse

Rather skinny and emaciated

At the eastern bank they were received

By Kyai Kapedhak of Beton.

When the members of the procession have been ferried across to the other side of the river, they discover that the priyayi guests have already arrived en masse. Feeling rather put out at this, many of the merchants decide to leave. The priyayi go off by themselves to sit in chairs, eat, and get drunk once again, paying no heed to the wedding ceremony that is taking place. While the nuptial rites proceed, the irrepressible men grab the hired female dancers to start up another tayuban:

...

tan dangu panganten prapti

ki tamu wus padha wuru

nora pati amarsudi

gendhing muni kebogiro.

Gendhing prapta ing kurmat penganten rawuh

anggepira para tami

kancane ingkang anjaluk

ringgit tinarik manginggil

samya jengklek pacak githok.

Pangantene kapiran duk apepangguh

mung para batur lan estri

kang upacara duk pangguh

datan kena den sayuti

panayube para dhayoh. ${ }^{38}$

Before long the groom arrived

The guests were already drunk

And didn't trouble themselves too much

The song that played was Kebogiro.

The song was played to hail the arrival of the groom

But the assumption of the guests

Was that one of their friends had requested it

${ }^{38}$ Ibid., verses 61-63, p. 191. 
A dancer was pulled up

All of them turned their necks [i.e., all began to dance in the tayuban]

The bride and groom were ignored during the rites

Only the servants and women

Attended at the ceremony

It was impossible to restrain

The dancing of the guests

Those sudagar guests who did not leave from the start make a hasty exit when they realize that no chairs have been set out for them. Meanwhile, after dancing, eating, and imbibing to their hearts' content, the priyayi guests go home without bothering to congratulate the bridal couple and without offering the customary sumbangan, "contribution" or gift.

Night after night the priyayi continue to show up at the merchant's house to continue the festivities. At Mr. Adjutant's urging, they are provided with great quantities of food. Only when everything in the merchant's possession has been cleaned out are Mr. Adjutant and his priyayi friends finally satisfied:

$\ldots$

wus entek kebo sepuluh saben bengi akeh prapti sumbangan tan ana katon.

Sinaosan bebeke anyar dha nyatus

kejaba kang kebo sapi

parandene nora cukup

kinurasan duwekneki

dalah darbeke wong wadon.

Mas Wajidan katutugan sedyanipun, suka sagung mitraneki sabubare ponang tamu mitrane kang celak nglikik, ki Juragan teka joto.39

...

Ten water buffalo were finished off

Every night many [people] came

Contributions were nowhere to be seen.

Even though a hundred new ducks [were slaughtered]

Not to mention the water buffalo and cows

Still it was not enough

His possessions were drained dry

Including the property of his wife.

Mr. Adjutant was fulfilled in every way

His friends were all happy

After the guests went home

His [Mr. Merchant's] close friends laughed at him

Mr. Merchant was left speechless with astonishment.

${ }^{39}$ Ibid., verses 66-68, p. 192. 
Besides being dazed and disappointed, Mr. Merchant is also hungry, but he is ashamed to eat the food that has been set aside for others: ${ }^{40}$

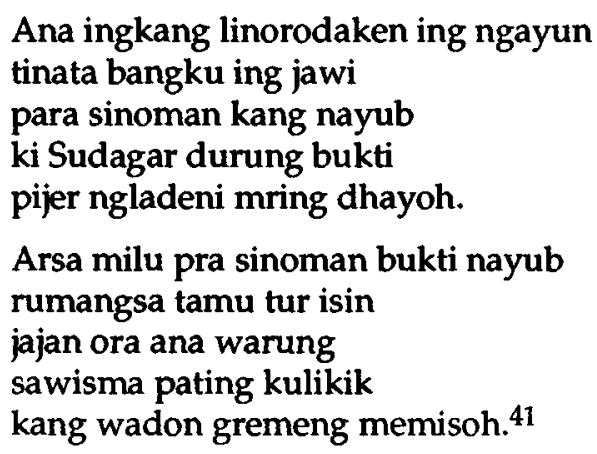

Arsa milu pra sinoman bukti nayub rumangsa tamu tur isin jajan ora ana warung sawisma pating kulikik kang wadon gremeng memisoh. ${ }^{41}$

Some food had been left out front Arranged on a table outside The servers were dancing Mr. Merchant hadn't yet eaten Having been too busy attending to the guests.

Were he to join the servers eating and dancing He would feel like a guest, and ashamed Wanting to eat out, no foodstalls were open The house was full of rumbling stomachs His wife grumbled and cursed.

Realizing that he has been made a fool of, and that he has seen not a penny in gifts to compensate for his expenses, he comes to the conclusion that all of his efforts have been completely in vain.

The moral to be learned from this debacle, the author tells us in the final verses, is that one should do things in the manner appropriate to one's own station in life:

Iku uga cacade wong amemantu dudu carane pribadi yen ngindhung caraning ngindhung priyayi cara priyayi dadi tan nganggo geguron.

...

Aja kaya kawruhe si kaki Pengung Sudagar cara Priyayi

yekti ngalor lawan ngidul dudu carane pribadi ngamungna kang wis kalakon. ${ }^{42}$

This is the fault of one who makes a wedding Not in keeping with his own ways

40 Ingkang linorodaken means "that which is set aside for those of lower status." Here, it refers to the food that has been put aside as a favor to the servers and other people of low status.

41 Jayadiningrat I, "Suluk Mas Ngantèn," Pupuh Megatruh, verses 69-70, pp. 192-93.

42 Ibid., verses 75-77, pp. 193-94. 
If you're a peasant, then do things like a peasant $\mathrm{t}^{43}$

A priyayi, then do things like a priyayi

Don't try to follow the ways of others.

$\cdots$

Don't do what that old fool did

A merchant who tried to do things like a priyayi

He went south when he should have gone north

It was not his own way

Don't repeat what's already over and done with.

It is hard to say who is more the target of Jayadiningrat's biting sarcasm in this poem: the foolish merchant who ruins himself and his family for his visions of priyayi grandeur, or the greedy and decadent priyayi who care about nothing but satisfying their own sensual appetites and being treated with great deference. Although Jayadiningrat is more direct in his criticism of the merchant, whose downfall results from his attempt to be something that he cannot be, the poem is also an acerbic comment on the self-indulgent lifestyles and overinflated egos of the members of the class to which Jayadiningrat himself belonged. These priyayi are not the noble, self-sacrificing pillars of morality, the brave and refined satria (knights), who would serve as aristocratic exemplars for the rest of the population. Rather, they are hedonistic, completely without shame, and totally unmindful of even the most basic etiquette (tatakrama). ${ }^{44}$

For all Mr. Merchant's troubles, he cannot cross the line between sudagar and priyayi; in the end, he is no more accepted by the priyayi than he was before. The only difference is that, whereas previously he was a merchant with a bit of money, now he is completely bankrupt. The author depicts merchant and priyayi as birds of a different feather, separate categories of people who have their own ways and travel in their own circles. It is significant, however, that, as a merchant, whom one would assume would place financial considerations above other concerns, Mr. Merchant is nonetheless willing to sacrifice all of his worldly possessions for the sake of the prestige that he would acquire should he succeed in being accepted into priyayi circles. His utter failure in this regard serves as a warning to anyone who would try to do the same. Still, this tells us something of the tremendous value placed on priyayi status. It also suggests that money and status were not equated-at least not in the eyes of the priyayi-and that even the most extravagant outlay of riches could not change the status of a merchant into that of a priyayi.

The poem points to the problem that wealth without power (power being a symbolic construct as much as a political one) creates in Javanese society. Wealth, of course, is what gives Mr. Merchant the illusion that he can break into priyayi circles, for the grandiose style

43 "If you're a peasant" is a loose translation, for lack of a better English equivalent, of the Javanese yèn ngindhung, which means, roughly, "if you live in a house owned by another." Horne offers the following translation for ngindhung: "to occupy (without owning) a house one has erected-by permission—on someone's property." Elinor Clark Horne, Javanese-English Dictionary (New Haven: Yale University Press, 1974), p. 237. Ngindhung, then, suggests being propertyless and dependent.

44 The "Suluk Mas Ngantèn" belongs to the genre of piwulang (poems of a didactic, often moralistic nature) literature. This was a common literary genre from the late eighteenth century through the nineteenth century. Soemarsaid Moertono writes that "Pizulangs were meant to fulfill specific contemporary needs, although of course they were based on traditional views and ideas. A careful reading of this genre of literature discloses the period's atmosphere of regret, of uncertainty and helplessness in the face of a reality too often unrelated to accepted standards of conduct." Soemarsaid Moertono, State and Statecraft in Old Java: A Study of the Later Mataram Period, 16th to 19th Century (Ithaca: Cornell University Modern Indonesia Project Monograph Series no. 43, 1981), pp. 46-47. 
of sudagar weddings, "all gold and silks," was clearly modelled after the opulent displays of the aristocracy. In the sudagar community, it is the display of wealth that generates and reproduces status: where the wealth comes from is less important than the fact that it is seen. Among the sudagar, wealth itself is the source of authority and of the ability to command deference. It is the foundation upon which hierarchy is constructed. Without wealth, a merchant is nothing more than one of the wong cilik, the "little people."

In priyayi ideology, however, wealth signifies something else. It is a sign, but not the source, of authority, of power, of the right to expect deferential behavior and language. A show of wealth with power is magnificence; a show of wealth without power is mere garish display, particularly when the wealth originates with something as profoundly acultural as trade. The richest of traders is still a commoner. Mr. Merchant, then, is a nouveau riche (not even an especially well-heeled one, the poet tells us) among aristocrats, a source of entertainment for them. He and his fellow merchants can be ignored, and their wedding made a mockery of, because sudagar wealth does not stand for anything besides itself-power, rank, or authority, for instance. It is wealth without substance. Yet the sudagar must be ridiculed, it seems, precisely because of the threat that their money poses for priyayi ideology. The possibility that wealth can be translated to status challenges power, all the more so when that "power" itself is bestowed, and can be taken away just as easily, by the real power-the Dutch colonial authorities.

Firmly established by the early nineteenth century, if not earlier, the sharp conceptual division between priyayi and sudagar remained fixed throughout the remainder of the colonial era and beyond. I emphasize the word "conceptual" because, although this division did correspond in some cases to clearly demarcated social classes, the perception of difference often exceeded the social reality, as we shall see. "Priyayi" and "sudagar" were categories based on what sometimes amounted to little more than an illusion of difference.

\section{Contested Hierarchies}

The relationship between the merchant class and the priyayi in Solo was thus an ambivalent one. It was a relationship marked by mutual suspicion and condescension, but not infrequently tinged with jealousy. To the members of the nobility and colonial bureaucracy, the characteristics of the merchant class epitomized the qualities that they claimed to despise, Jayadiningrat's sarcastic portrayal of the priyayi notwithstanding: greediness, devotion to material rather than spiritual pursuits, and cultural boorishness. The priyayi saw themselves as the inheritors and protectors of a venerable cultural tradition that had been passed down from generation to generation, while the sudagar, in their eyes, were ostentatious bumpkins in fancy clothes and gaudy jewelry, with no taste, no culture, and no sense of proper etiquette. They were worse than peasants because they did not know their place, refusing to acknowledge the superior status of the priyayi. Moreover, as we have seen, their successes violated the ideological principle that wealth should emanate from the center of power. Coming to them through commercial activity rather than through power and service to the state, the wealth held by the merchants was illegitimate as far as the priyayi were concerned. It was, in short, wealth that refused to assimilate itself to the established hierarchies of the society.

The merchants were no less harsh in their judgments of the priyayi than the priyayi were of them. Criticisms that I heard in Laweyan about the nobility and civil servants (pegawai negeri), the modern-day priyayi, echoed complaints about the priyayi that had resounded for generations in the merchant community. The priyayi were accused of being lazy, decadent, corrupt, arrogant, and of being perpetually dependent on the good graces of their superiors 
in what was perceived as an endless chain of patronage and sychophancy. Members of the merchant class deliberately contrasted themselves with the priyayi, asserting their autonomy and taking pride in their willingness to work hard for a living, something that most priyayi were incapable of, they said. One entrepreneur I knew summed up this attitude rather bluntly: "People here [in Laweyan] aren't 'yes men' [she used the English term, even though she was speaking Indonesian]. We don't like to be told what to do. We have the spirit of traders, we work for ourselves. We don't like to receive wages from others. And we don't like to ass-kiss" (ndak suka menjilat, lit: "don't like to lick"; she stuck out her tongue to emphasize the point when she said this).

The contempt, mixed with envy, that the merchants held for the priyayi as a class was reflected in their responses to, and interactions with, local representatives of the Kraton and the colonial bureaucracy (and later, the postcolonial state). In the sudagar community wealth, not rank, was the key to status. Although the merchants were certain to act respectfully in personal encounters with the priyayi, they were privately scornful of those priyayi who had no wealth to show for their position. Writing in the 1920s about Kotagede, a town which, like Solo, had both a strong indigenous Javanese bourgeoisie and many abdi dalem (in this case, representatives of both the Yogyakarta Sultanate and the Sunanate of Solo), the colonial administrator $H$. J. van Mook remarked of the richer merchants and entrepreneurs that

In them nothing is to be detected of the obsequiousness usual in the Principalities, for many of them are, on a lesser scale, what Rothschild was on a grand scale: the creditors of princes. They form a highly exclusive coterie which up to the present has held itself pretty much aloof from the activities of the recently created kelurahans [neighborhood or village administrative units]. ${ }^{45}$

He also commented that

The administrative officials [in Kotagede] have much less influence there than elsewhere, especially when they are not well-to-do. It is often difficult, and financially disastrous, for them to keep up with the wealthier inhabitants of Kuta Gede. ${ }^{46}$

Mitsuo Nakamura, confirming van Mook's findings, adds that "The majority of the wealthy merchants [in Kotagede] remained rather indifferent to the prestige deriving from the court." 47

A number of Laweyan merchants whom I knew expressed sentiments that continued to reflect this attitude. Some were puzzled, even amused, at the notion that anyone would want to become an abdi dalem when the wages were so low. Of course, they recognized that people became abdi dalem because of the prestige associated with it, but obviously it was not a source of prestige or pride with which they could easily identify. Most saw service to the court as a rather foolish waste of time, time which could be better spent pursuing more remunerative activities. Serving the palace didn't pay, but it was work. And work, they believed strongly, should pay.

Examining the overt opinions and stereotypes of each group about the other brings into focus some of the ideological issues that divided them, but it does not reveal the discrepancies between ideology and practice, nor the underlying complexity of the relationship

\footnotetext{
45 Van Mook, "Kuta Gede," p. 288.

46 Ibid., p. 28

${ }^{47}$ Nakamura, The Crescent Arises, p. 53.
} 
between the two groups. In order to better understand the nature of this relationship, it is helpful to look at the institution of marriage and how this served both to demarcate the differences and to obscure the commonalities between merchants and priyayi in Solo.

On the question of why there had been so few marriages between the sudagar families of Laweyan and Solo's nobility-for the wedding of wealth and noble status would seem to be a natural course of events-I received a number of opinions, each of which reflected a different source of tension between the two groups. Many merchants expressed doubt and even indignation when I suggested that it was the Kraton's decision not to allow marriages with Laweyan (cf. the reputed prohibition of marriage between the Kraton and Laweyan resulting from Pakubuwana II's experiences in the latter neighborhood) and not vice versa. Some insisted that, in fact, the opposite was the case: that the Laweyan sudagar wanted nothing less than to marry their children off to nobility. They pointed out that to marry into the royal family would likely mean bankruptcy for any merchant family, since the palace's demands for "contributions" would be unceasing (we need only refer to the "Suluk Mas Ngantèn" and Mr. Merchant's financial ruin to imagine this sort of scenario). Countering this, several priyayi argued that the sudagar would have been all too happy to have their children marry spouses with noble titles, but that the priyayi themselves found the merchants of Laweyan to be too concerned with matters of money to be acceptable as bésan (the parents-in-law of one's child). ${ }^{48}$ They commented that many merchants would have counted themselves extremely lucky to have grandchildren with noble titles and a streak of "blue blood."

One batik merchant offered another opinion on why marriages between Laweyan men and women of the nobility had been so rare. She observed that in the past, almost all Laweyan women had earned a living as batik entrepreneurs and traders, but women of high nobility had rarely done anything productive besides cooking or making batik as a handicraft during their leisure time. "People in Laweyan probably thought that noblewomen wouldn't want to do the coarse (kasar) kinds of work that women here were used to doing," she suggested. Aristocratic ladies would not have been happy to do such work, she added, nor would their families have seen fit for them to do it.

The nobility looked askance at the involvement of women traders in the market, a place that they associated with things kasar and of low status: coarse language, lust for money, and too much unrestrained association between the sexes. As the appointed custodians of the alus, the refined, they declared it a place unsuited for their own women to work. A granddaughter of a former sunan remarked that in the old days, kings were forbidden to marry traders because of their reputation for being "loose." We can understand from this why, though it was not unusual for women of high rank to contribute substantially to the income of their families by crafting batik in their homes and selling it from hand to hand, it was unthinkable for them to trade their batik in the marketplace. Bu Kartika, whose father had been a Mangkunagaran regent (bupati) during the last decades of colonial rule, recalled how her aristocratic mother had quietly supplemented her father's income: "Even as a regent, my father didn't earn enough to support the family. He would turn his salary over to my mother, and say to her, 'Here-if this isn't enough, you'll just have to make do somehow.' So she made money by selling her batik. But she wouldn't sell it to just anyone, and

\footnotetext{
${ }^{48}$ Bésan is a convenient term for which English has no exact equivalent: it designates the relationship between two sets of parents whose children are married to each other. Thus, bésanan means "to be mutually related as parents-in-law." Since marriage in Java is seen as a union of families rather than of individuals, the relationship of bésan is an important one. The concept of bésanan puts the emphasis less on the relationship between husband and wife than on that between their two sets of families.
} 
she never sold her batik in the market. There were prohibitions (larangan) on work for ladies of high status-the work they did had to be something that could be done at home, something that didn't stand out too much."

The different positions of women in these two classes of competing elites-the merchant class, in which women occupied pivotal economic and social roles outside the home, and the class of high-ranked nobility, in which women's productive activities were largely confined to the home-further symbolized the alus/kasar contrast and accentuated the social and ideological gaps between the two groups. If it was true that the nobility did not want their daughters engaging in "coarse" work, it was also the case that the merchant families of Laweyan had no use for women who would not work, because a work ethic for women was one of the most notable features of the community. As one woman merchant stated straightforwardly, "In Laweyan, the term ndara (a term of address used for someone of high rank) means someone who doesn't want to work."

Nor was the likelihood of Laweyan women marrying noblemen any greater: as I mentioned earlier in connection with the legend of Pakubuwana II's cool reception in Laweyan, sudagar women did not relish the thought of being dependent on aristocratic men. The most feared consequence of marrying a priyayi was being made a co-wife (dimadu), possibly one among several wives. Although polygyny was not unknown in the merchant community, it appears to have been less common than among the priyayi, perhaps because the typical sudagar man relied so heavily on his wife to manage the family business that he could not afford the possibility of incurring her wrath, or even the possibility of her demanding a divorce. Divorce was considered a preferable alternative by some women to being made a co-wife, but it was truly a dire prospect for a sudagar man of Solo, for it meant losing access to his wife's business skills and property. ${ }^{49}$

In the sudagar community, women's value was intimately linked to their economic productivity, which depended upon their ability and willingness to trade in the marketplace. Among the aristocracy, on the other hand, female value was tied much more to the domestic sphere, and to men's control over women's sexuality, fertility, and movement. Daughters were most valuable insofar as they could be used to forge politically expedient marriage alliances, ${ }^{50}$ while wives were assigned the basic tasks of serving their husbands, reproducing their husbands' lines, and maintaining the household. The place of the noblewoman was in the home, her movement in public increasingly restricted the higher her father's or husband's rank. ${ }^{51}$ The pasar (marketplace) represented the antithesis of the dalem (here in its double meaning of "home" and "an aristocratic residence"): it was a place where men could not control women.

\footnotetext{
${ }^{49}$ In her research on divorce practices in Java, Hisako Nakamura found that "sharing husband with another wife" (her translation of "dimadu"; this included the prospect of being made a co-wife as well as the fact of already having been made a co-wife) was recorded as the second most common cause of divorce in Kotagede from the years 1964-1971. The one reason given more commonly as the cause of divorce was "neglecting marital obligations" (on the part of either husband or wife). See Hisako Nakamura, Divorce in Java: A Study of the Dissolution of Marriage among Javanese Muslims (Yogyakarta: Gadjah Mada University Press, 1983).

50 Cf. Carey and Houben, "Spirited Srikandhis."

51 The best-known instance of female seclusion in Java is that of Radèn Ajeng Kartini (1879-1904), the daughter of a Jepara regent whose letters in Dutch were published under the title Door Duisternis tot Licht (Through darkness into light) seven years after her premature death at the age of twenty-five. Much has been made of the figure of Kartini, who attained the stature of a national heroine after Indonesian independence. An English translation of her letters was published under the title Letters of a Javanese Princess, translated by Agnes Louise Symmers, edited by Hildred Geertz (New York: Norton, 1964).
} 
Between these two ends of the priyayi-sudagar spectrum, however, was a gray area in which the distinction was blurred. It was in fact quite common during the late colonial period for the wives of lower- and middle-ranked priyayi to support their families as batik entrepreneurs and merchants while their husbands worked in prestigious but low-paying jobs. This pattern was most pronounced in neighborhoods of Solo near the Kraton that had a sizable corps of court retainers: the Kauman, Kratonan, Pasar Kliwon, and Kemlayan; Keprabon was another such neighborhood, but associated with the Mankunagaran palace instead of the Sunanate. In the Kauman, for instance, which was the religious hub of the city and site of the Great Mosque (Mesjid Agung) of the Sunanate, many women supported their households through the batik trade while their husbands served as Islamic officials (penghulu) at the Kraton or as religious teachers in the community. ${ }^{52}$ As Shiraishi comments, "... in central parts of the city such as Kauman there emerged no independent class of native bourgeoisie, even though there were numerous batik workshops and many batik entrepreneurs amassed wealth. In Marco Kartodikromo's words, batik entrepreneurs in this area were 'still in the family' with sunan's officials." 53

From a practical standpoint, not many priyayi men could afford the luxury of keeping their wives at home. ${ }^{54}$ In the case of those who were polygamous, small salaries had to be stretched even further to meet the needs of several wives and their children. Moreover, wealth contributed importantly to relative status: even for the priyayi, there was no honor to be gained in living on a pittance. A man of rank needed the material accoutrements of rank to support his claims to status. Thus, although priyayi ideology devalued trade, priyayi practice was not always in line with ideology. Because a family's status was defined much more by the social position of the husband than of the wife (which made it possible, for instance, for the sunan to marry a commoner woman and still sire royal children), the wife of a priyayi could engage in trade without her family being "demoted" from priyayi to sudagar status as a result. This was, of course, provided that neither her rank by birth nor her husband's rank was so high as to make trade out of the question.

Not all fields of trade were, however, equally acceptable. It would have been unseemly for the wife of a priyayi to peddle fruit, for example, or to open up a roadside foodstall at night. Since commodities, too, were evaluated hierarchically, it is no accident that the batik business was one of the few areas of trade open to priyayi women. ${ }^{55}$ Batik cloth, especially that which is crafted by hand, is considered an alus object through its connections to court culture (though there are relative standards of alus and kasar, refined and coarse, by which

\footnotetext{
52 The practice of seclusion for women was strikingly absent even in the Kauman, among the most orthodox Javanese Muslims of the city (I stress Javanese Muslims because seclusion of women had not been uncommon in Solo's Arab community). Even relatively long-distance trading was not unusual for Kauman women, and trading textiles in the marketplace was considered quite respectable.

53 Shiraishi, An Age in Motion, p. 25; Mas Marco Kartodikromo, Student Hidjo (Semarang: N. V. Boekhandel en Drukkerij, Masman \& Stroink, 1919), p. 6. A similar pattern existed in Yogyakarta, where batik families of the Kauman were often in service to the Sultanate as well. Mitsuo Nakamura, for instance, notes that Kyai Haji Ahmad Dahlan (1868-1923), the founder of the Islamic reformist organization Muhammadiyah, was both an Islamic official of the Yogyakarta Sultanate (for which he received a meager salary) and a batik merchant (The Crescent Arises, p. 46). Although Nakamura does not mention Ahmad Dahlan's wife's role in the business, women were as heavily involved in the batik trade in Yogyakarta as they were in Solo.

54 This was probably even more the case after the abolition of the appanage system in the first two decades of this century. The substitution of cash salaries for appanages meant that most officials had much less access to wealth than before.

55 Another object that was "respectable" for high-status women to trade was jewelry (especially gold and precious stones), which, like batik, had associations with court culture.
} 
individual pieces of batik are judged). One might say that the commodity itself brings an aura of respectability to the field of trade that surrounds it. Women of the highest rank were expected to make batik at home; this was a sign of cultivation and a refined leisure-time activity. ${ }^{56}$ The wife of a regent, as we have already seen, could unobtrusively sell the batik cloth she made to friends and acquaintances without being subject to criticism; for a "gift" of batik to be reciprocated with a "gift" of money was perfectly in keeping with standards of propriety. The shift, from making one's own batik and selling it to buying and selling other people's batik, was incremental; it did not require a great conceptual leap. Batik was still alus, even if trade was not. The batik business can therefore be seen as a nexus between alus and kasar, as culturally valued, alus objects are transacted in the kasar sphere of the market.

In another union of alus and kasar, many families of the Kauman and certain other neighborhoods of Solo were neither "purely" priyayi nor "purely" sudagar-they were hybrids. Here, priyayi and merchant lived under one roof as husband and wife. Some had ties of blood to the Kraton, as indicated by noble titles like Radèn Mas among the men or Radèn Ayu among the women. Batik workers and servants in such households addressed their employers deferentially as "Dèn" (from radèn) or "Ndara" (from bendara, master or mistress) instead of "Mbok Mas," the term of address commonly used in Laweyan for female employers without rank. This suggests that the boundary between priyayi and sudagar was not as impermeable as it seemed: it was an imagined boundary that could be crossed under numerous circumstances. Even inside the palaces of Central Java, there was a long history of women managing court finances and engaging in certain types of trade. ${ }^{57}$ Peter Carey and Vincent Houben, for example, remark that in the early nineteenth century, members of the Sultan of Yogyakarta's elite corps of women soldiers (prajurit èstri) were involved in "frenetic trade in gold and precious stones between Yogya[karta], Kutagede, Surakarta and the north coast." 58 The Laweyan stereotype that women of the nobility "would not work," then, was not particularly accurate, for even those women who would have found selling batik in the marketplace unacceptable often earned money through other kinds of activities.

Being labelled as "priyayi" or "sudagar" was not solely a matter of occupation, since a woman could be a full-time merchant and still be identified as priyayi by association with her priyayi husband. It was his social standing that fixed the family's identity more or less irrevocably as priyayi or sudagar. Those who would posit a clear cultural division between merchant and priyayi, then, have not taken into account the actual overlap that existed between the two categories, made possible by the discordance between ideology and practice, and by the gendered division of symbolic labor in the household that enables men and women to produce status for their families in very different ways. In the courts, as in the wider society, women, unlike men, could handle money without loss of prestige. Hence, in the early nineteenth century it was usual for one of the high-ranked ladies of the Kraton to manage the household expenses and to look after all the contents of the inner court, including the sunan's gold and jewelry. "All this stood in marked contrast," write Carey and Houben, "to what was expected from the male members of the court, both relations of the ruler and senior officials, who were not supposed to soil their hands with business ven-

\footnotetext{
56 See J. S. Furnivall, "The Weaving and Batik Industries in Java, with Notes on Hat Making and Soap Boiling," The Asiatic Review, 32 (110) (1936): 365-76.

57 Nancy Florida, personal communication; Carey and Houben, "Spirited Srikandhis."

58 Carey and Houben, "Spirited Srikandhis," p. 23; see Kumar, "Javanese Court Society," on the late eighteenthcentury diary of a woman soldier in Solo.
} 
tures." 59 The term "sudagar" did not only signify "merchant"-as a social and conceptual category, it also implied "those who are removed from the hierarchies of court and state." A peripheral neighborhood on the outskirts of town, Laweyan, unlike the Kauman, was the apotheosis of a sudagar community, for it identified itself precisely in opposition to the Kraton. Virtually none of its residents had any claims to priyayi status. Laweyan's merchants sought to create their own independent hierarchies based on wealth instead of title. A bécak (pedicab) driver, looking around at the imposing homes that dominated the neighborhood, put it most succinctly: "This is a place of royalty. But the rulers are all women. None of the men have any rank."

Even for Laweyan, however, the contrast between merchant and priyayi should not be overdrawn. Several of the most staunchly anti-Kraton merchants had grandfathers and great-grandfathers who had served the Kraton as abdi dalem. Furthermore, the wealthier and more established the sudagar became, the more they seemed to emulate the priyayi in certain aspects of their lifestyles, while continuing to voice their contempt for priyayi values. This was apparent, for instance, in their sharply asymmetrical relations with their employees; like the abdi dalem at court, the servants and batik workers of Laweyan employers were expected to speak to them in high Javanese and be answered in low Javanese, to come at their beck and call, and, in some cases, to kneel and avert their eyes when they served or spoke to them. Although most sudagar found the notion of serving others distasteful, this did not mean that they disliked having others serve them, or that they were any more egalitarian than the priyayi in their outlook.

The apparent "indifference" of the sudagar toward the priyayi frequently gave way to a more active rivalry, through displays of wealth reminiscent of those of the royalty, which few lower-ranked priyayi could match. Sudagar weddings and other ritual celebrations were extravagant exhibitions modelled after court ceremonial. No doubt the impressive diamond ornaments worn by women merchants and entrepreneurs and the bejewelled krisses sported by their husbands, visible indicators of success in business, were a constant, irritating reminder to the nobility that jewels did not necessarily go hand-in-hand with blue blood. This irritation, in fact, is still in evidence today. A woman from a high-born Mangkunagaran family whom I became acquainted with, herself involved in the batik business on a small scale, wrinkled her nose in distaste as she recalled the styles worn by Laweyan women in the past: "We never wore selèndang (a long scarf worn over one shoulder), because that was what all those traders in Laweyan wore. And then, they always went around showing off those big diamond earrings of theirs..." Even the spirits of the dead could be annoyed by a display of jewelry, as I discovered at the Kotagede cemetery, where visitors not of royal rank were asked to remove their jewelry in the presence of the royal tombs.

What have often been construed as markedly different cultural values dividing merchant and priyayi must be understood instead as an inversion or transmutation of values. The central focus of life in Laweyan, like elsewhere in Solo, was the attainment of status within the hierarchical structures that underlie Javanese society. The crucial distinction was that in Laweyan, the foundation of hierarchy was money, and status was based almost entirely on the acquisition and conspicuous expenditure of wealth. Here, the "aristocracy" consisted of those who had the most wealth-and especially, those who could hold onto their wealth from generation to generation. If this basis for acquiring status was more flexible than one based on rank, it was also more tenuous, for even the richest of merchant families could not be assured of everlasting prosperity. Everyone in the neighborhood knew

${ }^{59}$ Carey and Houben, "Spirited Srikandhis," p. 23. 
families that had fallen from great wealth to near destitution from one generation to the next, sometimes even within the same generation. The higher the status a sudagar family attained, the more it became obsessed with maintaining and reproducing that status. When the Sapardis crawled on their knees in Kotagede to invoke blessings of good fortune and good profits from the ancestral spirits of Java's royalty, it was a sign of their willingness to enter into the dominant hierarchies of Javanese society, at least temporarily, in order to secure an exalted place in the hierarchies of their own, more marginal, sector of society. 
